\title{
Berlin 1997
}

\author{
By Ron Holloway
}

Spring 1998 Issue of KINEMA

FOR THE FIRST TIME IN THE HISTORY OF THE BERLINALE,

or the first time in the history of the Berlinale, a Latin American entry was awarded the Golden Bear: Walter Salles's Central do Brazil (Central Station) (Brazil). And for the second time, Dutch animation director Gerrit van Dijk was awarded a Golden Bear for Best Short Film -- in 1989 for I Move, So I Am. Generally speaking, critics and public agreed that the festival prizes at the 48th Berlin International Film Festival (11-22 February 1998) went to the right films and directors.

Two Irish films were standouts. Jim Sheridan's The Boxer (a co-production with the USA) continued his insightful dialogue on the crisis in North Ireland -- together with In the Name of the Father (1993) and Some Mother's Son (1996) it appears to form a trilogy -- and confirmed once again that Daniel Day-Lewis is one of cinema's most committed and talented actors. Neil Jordan's Butcher Boy (Silver Bear for Best Director) also features a rooting performance by Eamonn Owens as a 12-year-old boy as a lad who escapes into his fantasies to blot out a tragic family life and time spent in a reformatory.

Of the American entries, Barry Levinson's polit-satire Wag the Dog was an advance sellout at the box-office due to its propitious (although unplanned) link to the ongoing Bill Clinton Media Show, but as a laugh-parade it was far outshone by The Big Lebowski, a nutty romp through the netherland imagination of a laidback "dude" from the '68 revolution (Jeff Bridges) by the team of Joel (director) and Ethan (scriptwriter) Coen -- indeed, the brothers enjoy a cult following in Germany second only to the late François Truffaut. And Quentin Tarantino's Jackie Brown, with rock-idol Pam Grier in the title role, had some moments of high L.A. crime drama when relieved of its hip one-word dialogue.

Of the European entries, actor-director Michael Gwisdek's Das Mambospiel (The Big Mambo) (Germany) held up well as a post-Wall tableau on an erstwhile filmmaker's movie-obsessed illusions in Cinderella Berlin just before it is to become the nation's capital. For my taste, The Big Mambo was as inventive in stylistic expression as was Alain Resnais's use of pop-tune-refrains in On connaît la chanson (Same Old Song, France) -- both, however, could have profited from generous cuts on the editing-table. The same is true of Danish director Nils Malmros's adaptation of Jørgen Frantz Jacobsen's novel Barbara (Denmark/Sweden/Norway): while a stunning film to look at, with the rugged Färöer Islands as a backdrop and the striking Norwegian actress Anneke von der Lippe as the vampire Barbara, it drags on long after the point of the 18th-century melodrama has been made, and enlarged upon, in a heavy musical score. Two lovely Spanish actresses also dominated by their very presence a pair of otherwise threadbare tales of love and despair: Laura Morante in Vicente Aranda's too lurid La mirada del otro (The Naked Eye, Spain) and Inès Sastre in Pupi Avati's stylish Il testimone dello sposo (The Best Man, Italy) set in December of 1899.

What would the Berlinale have done without Asian cinema (particularly since far too many directors absented themselves from press conferences)? Altogether, Moritz de Hadeln and Ulrich Gregor (Forum) booked 45 films from nine Asian countries, namely: 14 from Japan, 12 from Korea, eleven from China -- as follows: Hongkong/China (5), China (3), Taiwan (3), and Taiwan/China (1) -- two from the Philippines, and one apiece from Thailand and India.

Unfortunately, neither of the two Chinese feature films in the Competition -- Stanley Kwan's Yue kuai le, yue duo luo (Hold You Tight, Hongkong/China) and Lin Cheng-sheng's Fang lang (Sweet Degeneration, Taiwan/China) made for exciting cinema. Both were outclassed by a sympathetic American entry filmed in Mandarin: Joan Chen's Xiu Xiu, the actress's first film as a director. The story of a 16-year-old girl who volunteers with other teenagers to leave her urban home and school to "learn from the people" during the Cultural Revolution, Xiu Xiu is sent to a remote area on the rolling plains between China and Tibet on a six-month work-adventure -- then is promptly forgotten by government officials. Befriended only by a Tibetan horseman, she offers herself to passing men in hopes that one of them will free her from her ordeal and send her home. Xiu Xiu exemplifies the fate of some eight million teenagers who were lost to society or scarred for life by the Cultural Revolution between 1966 and 1976. But unlike the harsh reality depicted in 
similar films on the subject by Tian Zhuangzhuang, Chen Kaige, and Zhang Yimou, Xiu Xiu has a sweeter tone: in fact, some scenes were shot outside of China with an inappropriate musical score added during postproduction in a San Francisco studio.

As for Sweet Degeneration (Taiwan) and Hold You Tight (Hongkong/China), both are ventures into the erotic, the former dealing with a taboo relationship in Taipei and the latter scoring as the first Chinese-backed exploration into homosexuality. They also lacked the cutting-edge style of the official Japanese entry in the Competition: Nobuhiko Obayashi's Sada, awarded the International Critics (FIPRESCI) Prize. Drawing on the same true story that inspired Nagisa Oshima's Ai no corrida (In the Realm of the Senses), Obayashi traces Sada Abe's childhood and youth that led her in the 1930s to a life of "emancipated prostitution" and the murder of her lover in 1936, which both shocked Japanese morals and enshrined her as an icon of free love. Sada, a delightful film to watch, deftly employs jump-cutting, in-print colorization, and other experimental techniques to lift the chronicle neatly into the visual realm of dream and fantasy.

As though the prizes awarded recently at Cannes and Venice were not enough, the 28th International Forum of Young Cinema confirmed beyond the shadow of a doubt that "New Japanese Cinema" is currently the most exciting in Asia. Of the seven productions spotlighted by the Forum, Jun Ichikawa's Tokyo yakyoku (Tokyo Lullaby) links the new movement with the postwar classics made by Ozu and Naruse, while most of the others speak directly to the young generation -- e.g., the bizarre humor in Kobi Mitani's comedy Radio no jikan (Radio Time, or Welcome Back, Mr. McDonald), the surreal images in Masashi Yamamoto's Junk Food, the grotesque psychological twists in Sabu's gangster-drama Unlucky Monkey, the poetic minimalist portrayal of everyday life in Okinawa in Yosuke Nakagawa's Blue Fish, the subtly underscored identification with the victims of the Chernobyl tragedy in Saiichi Motohashi's documentary Nahja no mura (Nadya's Village), and the unusual thematic approach in Satoshi Kon's animation feature Perfect Blue. Kon's technical finesse had its parallel in a feature programmed in the festival's Main Program that's currently heralded as "the most successful film ever released in Japan": Hayao Miyazabi's Mononoke Hime (Princess Mononoke), set in magical forests during the blood-thirsty Monomachi period (1333-1568).

Korean cinema, which had already received a supportive boost by the newly founded Pusan film festival, was highlighted by the Forum with 14 films in a "Showcase Korea" section selected from the second Pusan festival. The series featured archival prints by cult director Kim Ki-yong (1919-1998) -- Ha-nyo (The Housemaid, 1960), Chung-nyo (The Insect Woman, 1972), Iodo (Io Island, 1977), and Ha-nyo '82 (The Housemaid '82, 1982) -- in addition to a broad spectrum of auteur filmmaking in Korea and a selection of videos by young independent directors. It was unfortunate that Kim Ki-yong had died just days before his Berlinale tribute, for his modest Forum retrospective revealed a cinema of striking imagery and lighting (admittedly influenced by German Expressionist filmmakers), an unorthodox editing technique, and a deep concern for social problems in postwar Korea.

Another Forum standout was Jie Zhang Ke's debut feature Xiao Wu (China), about adolescent pickpockets and smalltime cigarette-smugglers in the provinces of contemporary China; it was awarded the Wolfgang Staudte Prize. And in Rituparno Ghosh's Dahan (Crossfire, India), a complex statement about debased traditional codes and miscarriages of justice, it's a young educated Bengali woman who takes a determined stand in a court case to defend the honour of another afraid to do the same.

The 28th Forum will also be remembered for outstanding work in the documentary field. Ron Havilio's six-hour documentary Shivei Tmunot Yerushalaim (Fragments * Jerusalem, Israel, 1986-1997), a personal chronicle about an ancient city by means of archival photographs and rare film footage dating back to the middle of the last century, well deserved the FIPRESCI Award -- indeed, it scores as a modest masterpiece of long-term film reportage. Welcomed light was thrown on two of the most prominent personages of this century: Jutta Brückner's Bertolt Brecht -- Liebe, Revolution und andere gefährliche Sachen (Bertolt Brecht -- Love, Revolution and Other Dangerous Matters, Germany) bared conflicts and contradictions in the poet-dramatist's political stance and his oft-criticized relationship with female collaborators, while Oleg Kovalov's Sergei Eisenstein: Mexikanskaya fantasiya (Sergei Eisenstein: Mexican Fantasy, Russia), his second exploration into the creative secrets of the Russian master, offers us an entirely different and ravishingly beautifully print of the footage badly reconstructed in the 1931 versions of Que Viva Mexico and Thunder over Mexico. 
As for personal favourites, Lidiya Bobrova's $V$ toj stranje (In That Land, Russia), a Forum entry, recalled the cinema of the late Vasily Shukshin in which "little people," though scarred by war and poverty, still maintain their dignity. By the same token, Amos Kollek's Sue (USA), awarded the FIPRESCI Prize in the Panorama section, follows the descent into Manhattan oblivion of an innocent young woman unable to muster even a semblance of resistance against "down-sizing" on the workplace.

Lastly, Lothar Lambert's Und Gott erschuf das Make-up (And God Created Make-Up, Germany) opened the Panorama in grand Berlin Underground style -- indeed, this no-budget gay-comedy about therapy for transvestites in an apartment-commune sponsored by the city government (!) tweaks everybody's nose. The director's hometown popularity can be traced to a simple formula: here's a filmmaker who deftly handles every production chore save for standing behind the camera (Albert Kittler does the honors). This time, the madcap farce-maker has outdone himself: he gave the "Lambert Family" of professionals and nonprofessionals (most of them familiar names to the Berlin scene: festival photographer Erika Rabau, actress Dorothea Moritz, journalist Hans Marquardt, to name a few) some of their ripest, and kinkiest, roles.

\section{References}

\section{AWARDS}

Golden Bear

Central do Brazil (Brazil/France), Walter Salles.

Silver Bear, Special Jury Prize

Wag the Dog (USA), Barry Levinson.

Silver Bear, Best Director

Neil Jordan, Butcher Boy (Ireland).

Silver Bear, Best Actress

Fernanda Montenegro, Central do Brazil (Brazil/France).

Silver Bear, Best Actor

Samuel L. Jackson, Jackie Brown (USA).

Silver Bear, Lifetime Contribution to Art of the Cinema: Alain Resnais, for

On connaît la chanson), France/Switzerland/Great Britain).

Silver Bear, Outstanding Single Achievement

Matt Damon, screenwriter and actor, Good Will Hunting (USA).

Golden Bear, Short Film

I Move, So I Am (Netherlands), Gerrit van Dijk

Silver Bear, Short Film

Cinema Alcazar (Brazil), Florence Jaugey.

Blue Angel Prize

Left Luggage (Netherlands), Jeroen Krabbé.

Alfred Bauer Prize

Yue kuai le, yue duo luo (Hold You Tight, Hongkong/China), Stanley Kwan.

International Critics (FIPRESCI) Prizes: Competition

Sada (Japan), Nobuhiko Obayashi

Panorama: Sue (USA), Amos Kollek

Forum: Shivei Tmunot Yerushalaim (Israel), Ron Havilio.

Wolfgang Staudte Prize

Xiao Wu (China), Jie Zhang Ke. 
Ecumenical Prize

Central do Brazil (Brazil/France), Walter Salles.

\section{Author Information}

Ron HOLLOWAY (1933-2009) was an American critic, film historian, filmmaker and correspondent who adopted Europe as his home in the early fifties and spent much of his life in Berlin. He was an expert on the study of German cinema and against all odds produced, with his wife Dorothea, the journal German Film, keeping us up-to-date with the work of directors, producers and writers and the showing of German films around the world.

In 2007, Ron Holloway and his wife were awarded the Berlinale Camera Award. Ron also received the Bundesverdienstkreuz (German Cross of Merit), Polish Rings, Cannes Gold Medaille, the American Cinema Foundation Award, the Diploma for Support of Russian Cinema and an honorary award from the German Film Critics' Association.

Ron was also a valued contributor to Kinema for the past fifteen years. 